\title{
The Sources, Distribution Channel and Market Structure of Fuel Wood in Enugu State, Nigeria
}

\author{
F. E. Ebe \\ Department of Agricultural Economics, Michael Okpara University of Agriculture, Umudike, Abia State, \\ Nigeria.
}

\begin{abstract}
The study examined the sources, marketing channel and also determined the market structure of fuel wood in the study area. For the selection of the respondents, cluster random sampling technique was adopted. In the study, 90 fuelwood harvesters in the rural areas of the study were chosen and 90 fuelwood traders namely wholesalers and retailers were chosen from urban areas of the study. Data were obtained from the respondents through primary sources. These data were analyzed by using percentage and Gini-coefficient. The study revealed that fuelwood was sourced from open wood land/forests, privately owned land and plantations. The distribution channel of the wood product showed that when the fuelwood is harvested from its source, it is moved by the harvesters through wholesalers, retailers and finally to consumers. The findings on quality perception of fuel wood showed that majority of harvesters (98\%), wholesalers (89\%) and retailer (82\%) assess the quality of wood through high burning capacity of the wood. The analysis of Gini coefficient showed that there was low degree of concentration at all levels-harvesting, wholesaling and retailing as it recorded 0.16, 0.24 and 0.11 respectively. It also depicts that there is equality in the distribution of income among the fuelwood sellers. This shows that no fuel wood harvester or seller has control over the price of his/her good. The study concluded that further improvement is needed on fuel wood business for more efficiency of the trade.
\end{abstract}

Keywords: Fuel wood, marketing channel and market structure.

\section{Introduction}

Marketing is one of the vital issues in the production and distribution of goods and services. In the tree economy, there are two basic business, one is "production", that is the provision of goods and services. The other is "marketing" which consists of the activities by which goods and services from trees flow from the producer to the consumer [1]. This includes all the steps that are involved in moving the wood product from the place of harvesting/gathering until it gets to the users. It involves the activities associated with harvesting, transporting, selling and buying of the tree based products [2].

Fuelwood is a wood product that is sourced from forests/ open woodland, farm trees, and surpluses arising from agricultural land clearing. Most of the harvesting of fuelwoods is in the hands of many subsistence farmers who exploit trees for fuelwood especially during the slacked farming activities and often sell this to traders or consumers in urban centres. These traders in turn sell to the consumers in the urban centres. Fuelwood is wood burnt directly as fuel [3]. It is obtained from trees and shrubs [4]. It is a bulky and heavy material of low unit value and low price compared to conventional fuels. The overall direct cost of using fuel wood is generally lower than that of alternative fuels because unlike the latter, it requires only little investment in the purchase of secondary appliance. Fuelwood is the most accessible fuel even among urban households [5]. Until about two decades ago, there was little commercialization of fuel wood, before the inception of Structural Adjustment Programme (SAP). In those days, the demand for fuelwood was small in urban centres and there were fewer traders and intermediaries involved in this sector. The trade involved mostly the harvesters and the consumers. Nowadays with the increase in the demand of the wood product as a result of scarcity and non-availability of conventional fuels such as kerosene and cooking gas and constant increases in the prices of these fuels, shortages of fuel wood due to diminishing of forest and tree resources, fuelwood has become an important commercial good especially in the urban areas. The fuelwood business provides the poor households in the rural areas with extra income, offers employment opportunities and income to traders in urban areas and provides energy to the urban poor. With the increase in the volume of fuelwood trade, many intermediaries have begun the trade.

Despite the fact that fuel wood trade has increased in volume, markets for the wood products is still poorly developed compared to other products [6] unlike other agricultural products, the marketing of fuel wood is conducted entirely in open markets or along roadsides by the harvesters and traders without government intervention. The fuel wood harvesters at times display few bundles of fuel wood along the roadside where they wait for consumers, traders or transporters who purchase directly from them. The study therefore examined the sources and marketing channel of the fuelwood. It also evaluates the market structure with a view to determine and compare the degree of concentration of the fuel wood harvesters and traders. 


\section{Methodology}

For the purpose of the study, cluster random sampling technique was adopted for selection of harvesters. Enugu State was divided into three agro-ecological zones in line with political zonal structure. The zones are Enugu East, Enugu West and Enugu North. In each of the zones, sampling frame of clustercommunities where fuelwood are harvested in large quantities and traded or supplied to middlemen or consumers is compiled. The list of the communities compiled served as a sample frame. From the sample frame made in the three zones, nine rural communities were chosen i.e. three from each zone. The communities chosen were Amorji Nike, Ugwogo Nike and Amokpo Agu in Enugu East zone. In Enugu West, Enugu Agu Achi, Ahani-Achi and Mmam-Ugwoba while those selected in Enugu North were EhaNdiagu, Opi-Agu and Obimo. From each of the nine communities selected, 10 households that harvest and supply fuelwood to traders/middlemen in the urban areas were randomly chosen. Therefore, a total of 90 households/respondents that harvest and supply fuel wood were selected for the study.

For the selection of the traders (middlemen) three urban areas were chosen, namely: Enugu, Nsukka and Oji-River. This is because it is in the urban areas that fuelwood traders are concentrated, secondly urban people depend heavily on purchased fuelwood as most of them do not have the opportunity to source the fuel wood by themselves.

In the urban centres, fuelwood wholesalers usually stay together at some locations with large size of heaps of fuelwood; their staying together makes them to form association. Therefore, for the selection of the wholesalers, cluster random sampling was used. The urban markets used were Abakpa Nike Enugu, Nsukka urban and Oji-River urban. The register of the fuelwood association in each of the urban centres was used as sample frame. From the register, 15 respondents were randomly selected as fuelwood wholesalers. From the three urban centres, 45 wholesalers were randomly chosen for the study.

For the selection of the retailers in the urban centres, fuel wood retailers were often seen scattered in the streets with small sizes of heaps of fuelwood. In each of the urban centres, cluster of the fuelwood retailers was made. The clusters of the retailers used were Abakpa Nike Enugu, Ugwunzu in Oji River and Odenigbo in Nsukka.

A list of the fuelwood retailers in the clusters was compiled to serve as a sample frame, 15 respondents were randomly chosen from the sample in each of the urban area. In the three urban areas, a total of 45 retailers were selected and served with questionnaires. Therefore in all, 90 traders were used for the study.

Data for the study were collected from primary sources. The data obtained from the fuelwood harvesters included sources of fuelwood, types and quality of wood gathered and supplied, distributive channel, quantity of fuel wood supplied per period and prices of a tonne of fuel wood per period. For the middlemen (traders) information obtained from them included sources of their products, type and quality of wood purchased and sold, distributive channel of the wood, purchasing and selling prices per tonne for every month between April, 2005-March, 2006.

Statistical method by using percentage was used in analyzing the sources, quality of the fuelwood and part of market structure. The degree of concentration at each level of the harvesters, wholesalers and retailers was measured with Gini coefficient. Gini coefficient measures the degree of elements. It compares the Lorenz curve of a ranked empirical distribution with line of perfect equality. The Gini coefficient ranges between 0 where there is no concentration (perfect equality) and 1 where there is total concentration (perfect inequality) [7]. For instance a coefficient of 0.2 represents a lower level of inequality while 0.6 represents a situation where powerful elites dominate the economy. Gini coefficient that is greater than 0.35 are high indicating inequitable distribution meaning high inefficiency in the market structure [8,9 and 10]. Market concentration implies competition and this is measured by Gini coefficient. [11]. Brain and Jean-Paul (2005) used this tool to determine and compare the competition among traffic in various terminals. Therefore, Gini coefficient was used to found out the level of competition at each level among the harvester and the middlemen. To find the concentration of harvesters, wholesalers and retailers in the fuelwood market in the state, Gini coefficient was employed. The computation was based on sales revenue generated by the market participants (harvesters, wholesalers and retailers) on fuelwood. The revenue realized by the market participants in each zone for the period of the (April, 2005 to March, 2006) was used for the study. The computation formula used is shown thus;

$$
G=l-/ \sum_{k=0}^{k=n-1}\left(\partial X_{k-1}-X_{k}\right)\left(\partial Y_{k-1}+Y_{k} /\right.
$$

Where

$\mathrm{G}=$ Gini coefficient 
$\partial_{\text {share }}^{\mathrm{X}=} \quad$ Population

$\mathrm{Y}=$ Sales revenue share

$\mathrm{X}=$ Cumulated proportion of the population variable

$\mathrm{Y}=$ Cumulated proportion of the sales revenue

\section{Sources and Distributive Channel of Fuelwood}

\section{Results and Discussion}

Fuel wood is one of the most important sources of energy in Enugu State for domestic, traditional industries and commercial purposes. It is sourced from areas where it is transported to urban markets where the middlemen perform various functions. In the trade, the harvesters, middlemen and consumers link themselves. The linkage forms the marketing distribution channels. Therefore the distribution channel through which the fuel wood passes is shown in figure 1 below. Also the areas from where the respondents sourced the fuel

wood is shown in table 1 below.

Table 1: Distribution of harvesters according to sources of fuel wood

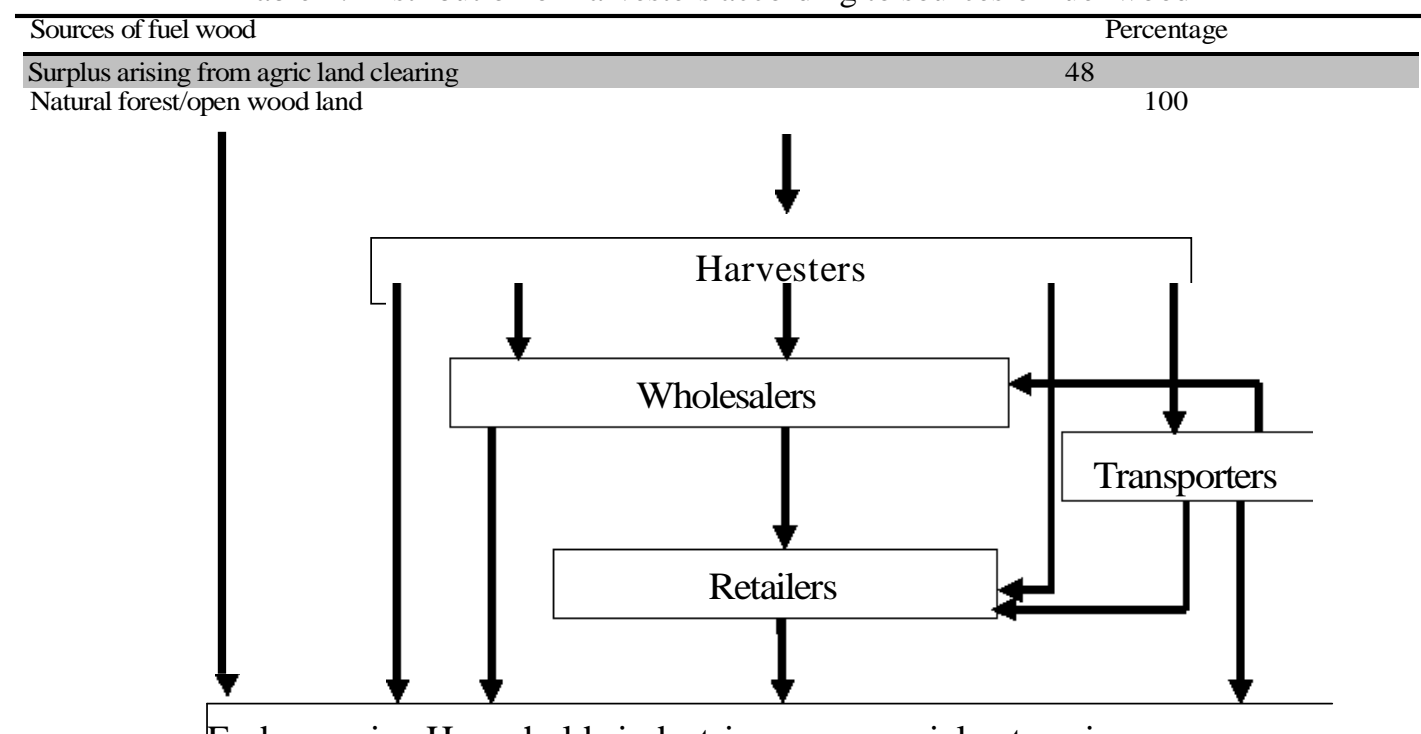

End-users i.e. Households industries, commercial enterprises

Plantation 14

Trees felled from privately owned land

Multiple responses recorded

Figure 1: Market distribution channel for FW

Sources of fuelwood Agric land clearing, forest/open

wood land private land and plantation

From table1 above, it shows that $100 \%$ of harvesters sourced fuelwood from forest/open wood land, $48 \%$ agricultural land clearing, and $29 \%$ privately owned land and $14 \%$ from plantation. The source from plantation came from government plantation located at Oji-River. The figure 1 depicts that the fuelwood is sourced by the harvesters. The harvesters then sell the goods to the wholesalers, retailers, consumers or transporters. The fuelwood is supplied in form of large pieces or trunk wood.

The wholesalers purchase the goods from the harvesters, transporters in form of large pieces or trunk wood. They later sell such wood to the retailers or chop them into smaller pieces either for sale to retailers or sell directly to consumers. The wholesalers who were non-indigenous to the communities where the fuel wood is sourced often buy the trees from the communities, fell, assemble, split and transport them to the cities where they resize and tie them in bundle and sell to larger consumers - commercial enterprises. 
The retailers buy from the wholesalers, transporters or the harvesters directly. The retailers in turn chop the wood into smaller pieces and sell them to the end-users.

The transporters are not purely in the distributive system of the fuelwood. They are those who convey goods from urban to rural areas. On their return trip to urban centre, instead of going back to the urban centre empty, they decide to buy the fuelwood, maybe along the road or in the farm and sell to those that need it. They sell either to retailers, wholesalers or consumers such as restaurants, bakeries and local brewing industries. These people sell at cheaper rate than those who are into the trade proper.

The big consumers e.g. bakeries and restaurants/hotels often bye pass the system by either buying directly from the harvesters, wholesalers or retailers. They employ their own labour to cut and transport the fuel wood to the factory.

\section{Quality Perception of Fuelwood by Buyers and Sellers}

Table 2: Distribution of fuelwood harvesters, wholesalers and retailers according to criteria used in assessing the quality of the fuelwood

\begin{tabular}{|c|c|c|c|}
\hline Criteria & $\begin{array}{l}\text { Harvesters } \\
\text { Percentage }\end{array}$ & $\begin{array}{l}\text { Wholesalers } \\
\text { Percentage }\end{array}$ & $\begin{array}{l}\text { Retailers } \\
\text { Percentage }\end{array}$ \\
\hline High burning capacity & 98 & 89 & 82 \\
\hline Maturity of the tree & 11 & 29 & 13 \\
\hline Less smoky & 69 & 33 & 38 \\
\hline Production of good charcoal and less ash & 50 & 56 & 40 \\
\hline
\end{tabular}

\section{Multiple responses recorded}

The market participants (wholesalers, retailers and harvesters) assess the quality of the wood through the knowledge of the tree that produces the fuelwood. The buyers and sellers observe the wood physically. They claimed that most often, white wood produce low grade of fuelwood while dark red and hardwood produce high quality fuel wood.

Majority of the harvesters (98\%), wholesalers (89\%) and retailers (82\%) assess the quality of the wood through high burning capacity. The assessment of the wood through maturity of the tree ranked the least as it recorded $11 \%$ harvesters, $29 \%$ wholesalers, and $13 \%$ of retailers respectively. This implies that the maturity of the tree does not determine the quality of the wood.

The overall result shows that high burning capacity had the largest proportion of the criteria. This implies that the wood burns high, quickens the cooking with less constant watch and gives less smoke. The wood that has such quality is referred to as high quality wood in terms of cooking.

\section{Determination of Market Structure}

Market structure includes number of firms, size of the firms and their size distribution, the degree of concentration and the ability of firms to differentiate their products and the barriers to entry into the industry [9]. One of the ways of determining the market structure is through concentration, and this is shown in the table below. Table 3: Analysis of Gini coefficient for determining the degree of concentration for the fuel wood market participants

Table 3: Gini coefficient for Harvesters

\begin{tabular}{|c|c|c|c|c|}
\hline Zones & Enugu & Nsukka & Oji-River & Total \\
\hline Sales revenue & $\$ 14,172,900$ & $\$ 10,910,200$ & $\$ 6,759,300$ & $\$ 31,842,400$ \\
\hline Population share $(\mathrm{X})$ & 0.3335 & 0.3335 & 0.3335 & 1.0005 \\
\hline $\begin{array}{l}\text { Sales revenue } \\
\text { Share }(\mathrm{Y})\end{array}$ & 0.4451 & 0.3426 & 0.2123 & 1.00 \\
\hline$\partial \mathrm{X}$ & 0.3335 & 0.667 & 1.0005 & \\
\hline \multirow[t]{3}{*}{$\partial \mathrm{Y}$} & 0.4451 & 0.7877 & 1.000 & \\
\hline & 0.3335 & 0.3335 & 0.3335 & \\
\hline & 0.4451 & 1.2328 & 1.7877 & \\
\hline $\mathrm{A}^{*} \mathrm{~B}$ & 0.1484 & 0.4111 & 0.5969 & \\
\hline$/ \Sigma(\mathrm{A} * \mathrm{~B}) /$ & & & & 1.1557 \\
\hline$/(1-\Sigma(\mathrm{A} * \mathrm{~B}) /$ & & & & 0.156 \\
\hline G & & & & 0.16 \\
\hline
\end{tabular}

Table 4: Gini coefficient for Wholesalers

\begin{tabular}{|l|l|l|l|l|}
\hline Zones & Enugu & Nsukka & Oji-River \\
\hline Sales revenue & N24,826,150 & N 13,491,500 & N 8,467,900 & N 46,785,650 \\
\hline Population share $(\mathrm{X})$ & 0.3335 & 0.3335 & 0.3335 & 1.0005 \\
\hline
\end{tabular}


The Sources, Distribution Channel and Market Structure of Fuel Wood in Enugu State, Nigeria

\begin{tabular}{|l|l|l|l|l|}
\hline $\begin{array}{l}\text { Sales revenue } \\
\text { Share }(\mathrm{Y})\end{array}$ & 0.5306 & 0.2884 & 0.1810 \\
\hline$\partial \mathrm{X}$ & 0.3335 & 0.667 & 1.000 \\
\hline$\partial \mathrm{Y}$ & 0.5306 & 0.8190 & 1.0005 \\
\hline & 0.3335 & 0.3335 & 0.3335 \\
\hline & 0.5306 & 1.3496 & 1.8190 & 0.6066 \\
\hline $\mathrm{A} * \mathrm{~B}$ & 0.1770 & 0.4501 & & \\
\hline$/ \Sigma(\mathrm{A} * \mathrm{~B}) /$ & & & & 1.2337 \\
\hline$/(1-\Sigma(\mathrm{A} * \mathrm{~B}) /$ & & & & 0.2337 \\
\hline $\mathrm{G}$ & & & 0.24 \\
\hline
\end{tabular}

Table 5: Gini coefficient for Retailers

\begin{tabular}{|c|c|c|c|c|}
\hline Zones & Enugu & Nsukka & Oji-River & Total \\
\hline Sales revenue & $\mathrm{N} 23,830,300$ & $\mathrm{~N} 17,410,500$ & $\mathrm{~N} 14,632,400$ & $\mathrm{~N} \mathrm{55,875,200}$ \\
\hline Population share $(\mathrm{X})$ & 0.3335 & 0.3335 & 0.3335 & 1.0005 \\
\hline $\begin{array}{l}\text { Sales revenue } \\
\text { Share (Y) }\end{array}$ & 0.4265 & 0.3116 & 0.2619 & 1.000 \\
\hline$\partial \mathrm{X}$ & 0.3335 & 0.667 & 1.0005 & \\
\hline \multirow[t]{3}{*}{$\partial \mathrm{Y}$} & 0.4265 & 0.7381 & 1.000 & \\
\hline & 0.3335 & 0.3335 & 0.3335 & \\
\hline & 0.4265 & 1.1646 & 1.7381 & \\
\hline $\mathrm{A} * \mathrm{~B}$ & 0.142 & 0.388 & 0.580 & \\
\hline$/ \Sigma\left(\mathrm{A}^{*} \mathrm{~B}\right) /$ & & & & 1.110 \\
\hline$/(1-\Sigma(\mathrm{A} * \mathrm{~B}) /$ & & & & 0.110 \\
\hline G & & & & 0.11 \\
\hline
\end{tabular}

The analysis of Gini coefficient for the determination of degree of concentration as shown in tables 3, 4, and 5 show that Gini coefficient for harvesters, wholesalers and retailers were 0.16, 0.24 and 0.11 respectively which indicate that the three levels depict low concentration. This implies that any of the levels, none of the harvesters, wholesalers or retailers could control a large share of fuelwood supply or influence the supplies either by increasing or reducing the quantity being supplied thereby influence the price. No one controls the significant portion of the market. Therefore none could influence the market price of his goods through his own decision or action. This means that market force prevails in the fuel wood market.

In comparing the degree of concentration of harvesters, wholesalers and retailers there was highest degree of concentration at wholesale level, followed by harvesting and lastly retailing. This reason adduced for this was that wholesalers trade association which makes them to be more organized, possess more capital and most of them take fuelwood business as their sole trade. This implies that they put all their available resources for the progress of the business, while at other levels (harvesting and retailing) most of them take it as part time business.

\section{Conclusion}

The study examined the sources, distribution channel and market structure of fuel wood in Enugu State. The result showed that fuel wood was sourced from open wood land/forest, privately owned land and plantation by the harvesters. Then the wood is moved from the harvesters to wholesalers, retailers and finally to consumers. The result on quality perception of fuelwood indicated that majority of the harvesters $(98 \%)$, wholesalers $(89 \%)$ and retailers $(82 \%)$ assess the quality of the wood through high burning capacity. The analysis of Gini coefficient showed that there was low degree of concentration at all levels- harvesting, wholesaling and retailing as it recorded $0.16,0.24$ and 0.11 respectively. This implies that no one at any level of fuel wood market controls large share of proportion of the business. This means that market force prevails.

The overall result showed that like other agricultural product, fuelwood is moved from its sources through the harvesters, wholesalers, and retailers down to the consumers. At the structural level fuelwood market exhibited perfect market structure where none of the participants was in control of the operation of the business. The study therefore concludes that there is need for further improvement on fuelwood business because the participants are not well organized. 


\section{References}

[1]. Adeyoju, S.K. (1975). Forestry and Nigeria Economy. Ibadan: Ibadan University Press.

[2]. Agarwal, B. (1986). Cold Hearth and Barren Slope: The Woodfuel Crisis. London: Zed Books Ltd.

[3]. Dillon, J.L and J.B. Hardaker (1993). Farm Management Research for small Farmer Development. Rome; FAO

[4]. Ezedinma, F.O.C. (1999). "Crop Science”. In; Youdeowei, A., F.O.C., Ezedimma and C.O Ochapa (eds), Introduction to Tropical Agriculture. England: Pearson Education.

[5]. Food and Agricultural Organisation (1985). Trees Growing by Rural People. Rome: F.A.O.

[6]. Hans, G.D., D. Sydney and E. Dieter (1989). People and Trees. Washington D.C. World Bank.

[7]. Ike, P.C and C.O. Chukwuji. (2005). Efficiency Measurement of Cashew nut Marketing in Enugu State, Nigeria". AgroScience. Vol.4, N0. 1, January. Pp46-49.

[8]. Katerere, Y. (1992). “The Valuation of Trees Based Resources: The Problem”. In: Kwaje, S.I and F.B. Mivanra (eds), Proceedings of the First Internal Workshop on Capacity Building in Forestry Research in Africa, Kampala, Uganda. Nov. pp9-1 1.

[9]. Kohls, R.I. and J.N. Uhl (1972). Marketing of Agricultural Products. New York: Macmillian Publishing.

[10]. Peters, S.W. (2000). "Energy Resources and Energy Policy in Nigeria". In : Ajaegbu, H.I; Mathew- Daniel, B.J. and O.E.Uya (eds), Nigeria, A people United A Future Assured. Abuja: Federal Ministry of Information.

[11]. Wikipedia (2005). Gini coefficient: www.wikipedia, the free encyclopedia 